\title{
Inventing the Myth: Political Passions and the Ulster Protestant Imagination
}

\author{
Connal Parr
}

Oxford University Press: Oxford, 2017, (hb) ix + 294pp., ISBN 9780198791591. £55.

As the depressing spectacle of inter-party talks designed to revive the Northern Ireland Executive dragged on sporadically through 2017, it became clear that one of the critical areas of division between the Democratic Unionist Party and Sinn Féin, alongside the complex legacies of the conflict, was the issue of cultural politics (or, at least, the political uses of culture). The ostensible sticking point of an Irish Language Act could be understood as a proxy for a much broader series of disputes surrounding questions of cultural expression and equality (in the language of the Good Friday/Belfast Agreement, 'parity of esteem'). For students of politics elsewhere, this concern with culture as a bone of contention in Northern Irish political life can seem rather esoteric. But, in a highly politicised society, in which many are sensitively attuned both to how their own 'community' is represented by the 'other side', and how they represent themselves to the outside world, these questions are of central importance.

In this important and ground-breaking book, based on extensive interviews, Connal Parr engages seriously with the politics of culture, particularly focusing upon the neglected Protestant working-class tradition within the theatre (and, to a lesser extent, television) in Ulster. He structures the book around ten writers, ranging chronologically from St John Ervine and Thomas Carnduff (both born in the 1880s), through to those born after World War 
Two, such as Gary Mitchell and Marie Jones. The overarching purpose is to illustrate the richness and complexity of this Protestant working-class writing, and the nefarious political consequences of reductionist accounts which seek to portray this culture in Northern Ireland as both monolithic and uniformly reactionary. In this dual purpose, the book succeeds admirably.

The main target of Parr's argument in the opening chapter is the routine cultural disparagement of Protestants by Irish republicans (exemplified by Ronan Bennett's 1994 dismissal of Protestant culture as 'little more than flute bands, Orange marches and the chanting of sectarian songs at football matches'). More surprisingly, but of critical significance to Parr, this malign interpretation of a stunted, unchanging culture is one which has been shared by many within the unionist political establishment; 'this appears to linger in the contemporary belief of many Protestants that they do not "do" the arts just as they do not “do" left-wing politics.' (p.7). Many of the writers studied have been engaged in a profound process of self-examination of the community into which they were born. As Parr observes, this kind of restless questioning has been alien to mainstream Unionist (with a capital ' $U$ ') politics, and this disjuncture is at the heart of the book.

In revealing the notion of a straightforward, homogeneous and reactionary culture to be a lamentable caricature, Parr is painstakingly engaged in a work of recuperation and refutation. The reality captured in close analysis of the work of playwrights like Sam Thompson and Stewart Parker, and poets such as John Hewitt, is that both in their conception and their reception, these works have reflected and shaped the diversity of a culture which is 'relentlessly dissenting and inherently creative.' (p.254). The labourist culture of mid-century (captured in Thompson's play Over the Bridge in 1960, and his political commitment to the Northern Ireland Labour Party) is of particular interest to Parr, and he underlines the power of Thompson's dissection of sectarianism in the Belfast shipyards. Part of this power resided in 
the play's uncanny ability to anticipate the violent conflict to come. Understandably, the Troubles loom large in the plays of a later generation of working-class writers, and probably the key text which the book analyses in this respect is Parker's Pentecost (1987). Parr puts forward a subtle analysis of the political context of the Ulster Workers' Council in May 1974, which is the setting of the play, and its characters are seen to represent the 'full panorama of the Northern Irish Protestant spectrum of experience.' (p.122). Parker himself argued that theatre was the medium in which he had the best chance of breaking down the 'deepest, most enduring and least tractable evil in our inheritance': namely, sectarianism. (p.120). Parker's early death in 1988 robbed the theatre in Ulster of one of its most articulate voices, but it is instructive to imagine the acerbic eye he would cast upon the contemporary political standoff in Northern Ireland.

The Protestant working-class in Northern Ireland, and its fragmented but rich culture, has often been maligned and misunderstood: by Irish nationalists and republicans, by Unionist politicians, and by many of those in Great Britain who have taken an interest in Northern Irish affairs (admittedly, a small number). For those who genuinely seek a nuanced and detailed understanding of its political and cultural dynamics over the course of the last century, they could do no better than delve into this hugely rewarding book.

\section{Stephen Hopkins}

University of Leicester

sh15@,1eicester.ac.uk 